\title{
Cashier Work Posture Analysis Using Rapid Upper Limb Assessment (RULA) and Quick Exposure Checklist (QEC): A Case Study in QRS Pharmacy
}

\author{
Rahma Fariza ${ }^{1, *}$ Riska Dwi Oktalia ${ }^{1}$ \\ ${ }^{1}$ Department of Industrial Engineering, Faculty of Industrial Technology, Universitas Islam Indonesia, Yogyakarta, \\ Indonesia \\ *Corresponding author. Email: rahmafrza@gmail.com
}

\begin{abstract}
Good posture can be an indicator of increased work productivity. This study was conducted to analyze work posture and to determine the level of risk of the upper body posture when working as a cashier at a QRS pharmacy. The research method is used in determining the object of research, collecting data, processing data, analyzing, and providing recommendations. Data processing and analysis techniques are Rapid Upper Limb Assessment (RULA) and Quick Exposure Checklist (QEC) using ErgoFellow software. The results showed that the operator's risk level worked in the medium risk classification with a final score of 5 and the exposure score of $60.49 \%$ or in the classification investigated further and changed soon. Work posture recommendations for operators can be supported by redesigning tools on chairs and tables so that they are more comfortable to use and doing stretching every certain unit of time.
\end{abstract}

Keywords: Ergonomics, Rapid Upper Limb Assessment (RULA), Risk Level, Quick Exposure Checklist (QEC), Work Posture.

\section{INTRODUCTION}

The definition of pharmacy according to the Regulation of the Minister of Health of the Republic of Indonesia No. 35 of 2014 is a place for pharmaceutical services that are carried out by pharmacists, and is a complement to health facilities commonly found in hospitals, clinics, or health centers [1]. This health facility in the pharmaceutical sector is a supporter in the supply of drugs and other medical equipment. Currently the pharmacy has developed into an independent facility without having to integrate with public health facilities. This indicates that the data collection process for drug transactions is also carried out independently. The cashier is the person responsible for the transaction.

In work activities, proper positioning will not only enhance the worker's productivity, but also decrease the incidence of injury and associated with health care costs [2]. If the position of the body at work is not ergonomic, it can cause workers to easily get tired and bone deformities can occur [3]. In addition, it can also cause MSDs (Musculoskeletal Disorder). MSDs are a condition of mild to painful complaints by workers in the skeletal muscle section [4]. One of the causes of MSDs in workers is inaccurate work posture [5].

Occupational risks such as MSDs can occur even in simple jobs. As in [6], a study on the Ergonomic Assessment of the Working Conditions of Checkout Counter Cashiers in a Grocery Store in the Philippines, it has been found that the cashiers are at high risk of developing Musculoskeletal Disorders development. However, in a budget-cut country, such as Indonesia, there are significant gaps in water monitoring activities. Coupled with the vastness of areas to be monitored, a limited capacity of human resources, and limited equipment, water quality monitoring is a complex problem at its peak. 
Another study about musculoskeletal as in [7], researching cashiers to find out the correlation between ergonomic analysis and their work stations using RULA. It was found that there was pain felt in the neck, shoulders, wrists/hands, lower and upper back. The score obtained is 6, which requires detailed investigation and short-term changes. In addition, musculoskeletal injuries are associated with ergonomic risks at work stations.

QRS Pharmacy is one of the pharmacies in Yogyakarta. One of the workers is a female cashier as a respondent who serves drug sales transactions, records transactions, packaging, and helps provide information about products to consumers. In an 8-hour workday, the cashier does her job mostly sitting down. So that the parts of the body that are actively working are only the upper part, such as the arms, hands, and back. Based on observations by researchers, it was found that the respondent's body posture was not quite right, namely bending. If this is done for a long time and continuously, it can cause complaints of pain due to poor blood circulation.

Based on the complaints of pain that can decrease the worker's productivity, efficiency, and effectiveness, the further research is needed to analyze work postures. The method that can be used according to the problem is RULA (Rapid Upper Limb Assessment) and QEC (Quick Exposure Check) so that it can determine the level of risk of upper body posture when working and know which body parts have a high risk so that appropriate recommendations can be given.

\section{LITERATURE REVIEW}

\subsection{Ergonomics Risk Assessment}

Ergonomics is a science that deals with the functional characteristics of humans. Ergonomics is a science that deals with the nature, abilities, and limitations of humans in designing work systems so that people can work well on the system and achieve work goals effectively, safely, and comfortably [8]. Risk assessment in accordance with ergonomic standards is important in the workplace for employees to identify risks that may occur and prevent these risks [9]. Risk identification can help workers protect themselves and prevent risks as early as possible, provide a safer workplace, and increase productivity levels.

\subsection{Work Posture}

Good work posture is determined by the movement of the body's organs when working. Ergonomics considerations related to comfortable work postures are used to prevent complaints of pain in body parts or called CTDs (Cumulative Trauma Disorders) and also referred as Work-Related Musculoskeletal Disorders (WMSDs). CTDs are skeletal muscle injuries that increase gradually due to repeated minor trauma due to poor working system design resulting in abnormal body movements [10]. Common CTDs include but are not limited to lower back pain, carpal tunnel syndrome, De Quervain's tenosynovitis, trigger finger, and many others [11].

\subsection{Workstation Design}

Work station design must be able to adjust workers in order to provide the best work performance, so that workers can work safely and produce effective and efficient work. The size of the work station can adjust the structure and to the movement of the worker's body. As in [12], study on the anthropometric measurement among four Asian countries in designing sitting and standing workstations, the anthropometric measurements were taken from Malaysian, Indonesian, Filipino, and Thai. According to the study, the height reach of a male and female Indonesian are $172 \mathrm{~cm}$ and $159 \mathrm{~cm}$, respectively.

\subsection{RULA}

RULA or Rapid Upper Limb Assessment was developed by Dr. Lynn Mc Atamney and Dr. Nigel Corlett, who is an ergonomics professor at the University of Nottingham, the University of Nottingham's Institute of Occupational Ergonomics. RULA was first described in the form of an ergonomics application journal in 1993 [13]. Rapid Upper Limb Assessment is a method developed in the field of ergonomics that investigates and assesses the working position of the upper body. This method is used to take the value of work posture by taking a sample of posture from one work cycle which is considered to have a dangerous risk for workers' health, then scoring is held. Using the RULA worksheet, the evaluator will assign a score to each of the following body areas: upper arms, forearms, wrists, neck, spine and legs. After the data for each region is collected and scored, the table on the form is then used to arrange the risk factor variables to produce a single score that represents the level of risk of MSDs.

\section{5. $Q E C$}

QEC or Quick Exposure Check is a method for assessing occupational risks associated with muscle disorders in the workplace on the back, shoulders/arms, wrists, and neck [14]. QEC helps to prevent the occurrence of WMSDs (Work-Related Musculoskeletal Disorders), such as repetitive movements, compressive forces, incorrect posture, and duration of work [15]. This method combines the assessment of the workload from the side of the researcher and the operator or respondent. Assessment is obtained based on an explanation of the level of risk for the back, shoulders/arms, hands and wrists and neck related to a particular job, and shows whether the ergonomics intervention has been proven effective (with the score fluctuating). 


\section{RESULT AND DISCUSSION}

\subsection{Data Collection}

The results of the recording process of cashier activities are then angled so that work posture data is obtained from three sides, namely the right side, the left side, and the upper side are shown in Figure 1-3.

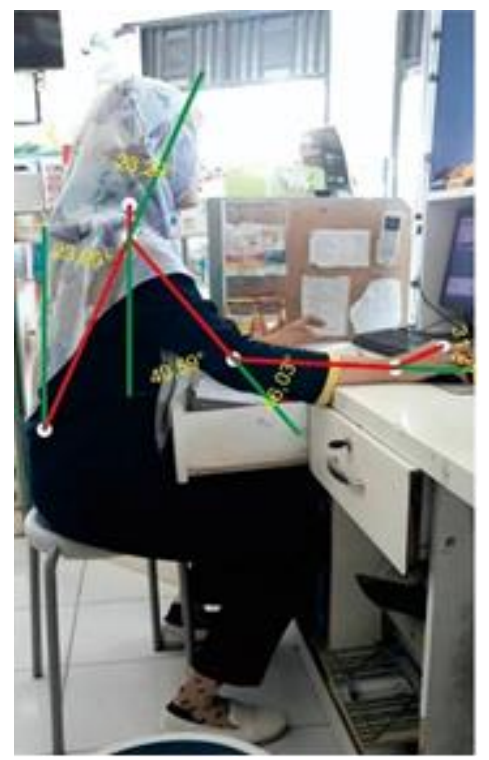

Figure 1. Respondents' Work Posture from the Right Side.

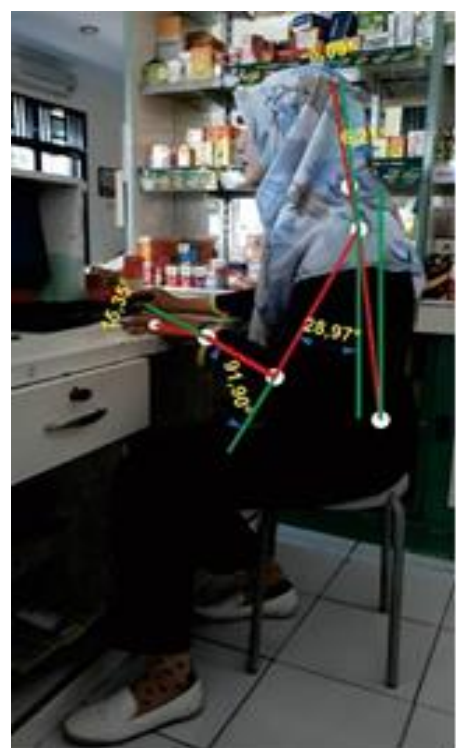

Figure 2. Respondents' Work Posture from the Left Side.

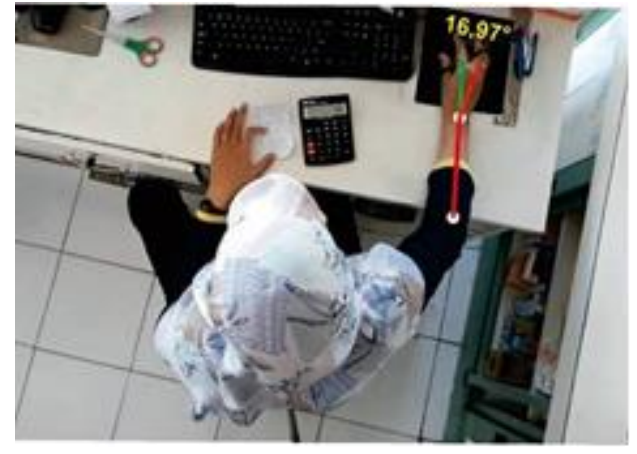

Figure 3. Respondent's Work Posture from the Top.

Table 1, Table 2, and Table 3 below show the angle formed by the body from the three sides.

Table 1. Respondents Working Posture Angle Right Side.

\begin{tabular}{|c|l|c|}
\hline No & Body Segment & Angle Shaped $\mathbf{(}^{\mathbf{0}}$ ) \\
\hline 1 & Upper arm & 40.59 \\
\hline 2 & Forearm & 46.03 \\
\hline 3 & Wrist & 31.27 \\
\hline 4 & Neck & 23.29 \\
\hline 5 & Back & 23.90 \\
\hline
\end{tabular}

Table 2. Respondents Working Posture Angle Left Side.

\begin{tabular}{|c|l|c|}
\hline No & \multicolumn{1}{|c|}{ Body Segment } & Angle Shaped $\left(^{\mathbf{0}}\right)$ \\
\hline 1 & Upper arm & 28.97 \\
\hline 2 & Forearm & 91.90 \\
\hline 3 & Wrist & 15.35 \\
\hline 4 & Neck & 3.09 \\
\hline 5 & Back & 6.21 \\
\hline
\end{tabular}

Table 3. Respondents Working Posture Angle Upper Side

\begin{tabular}{|c|c|c|}
\hline No & Body Segment & Angle Shaped $\left(^{\circ}\right)$ \\
\hline 1 & Wrist & 16.97 \\
\hline
\end{tabular}

The questionnaire data for assessing the level of risk of falling by researchers and respondents is shown in Figure 4

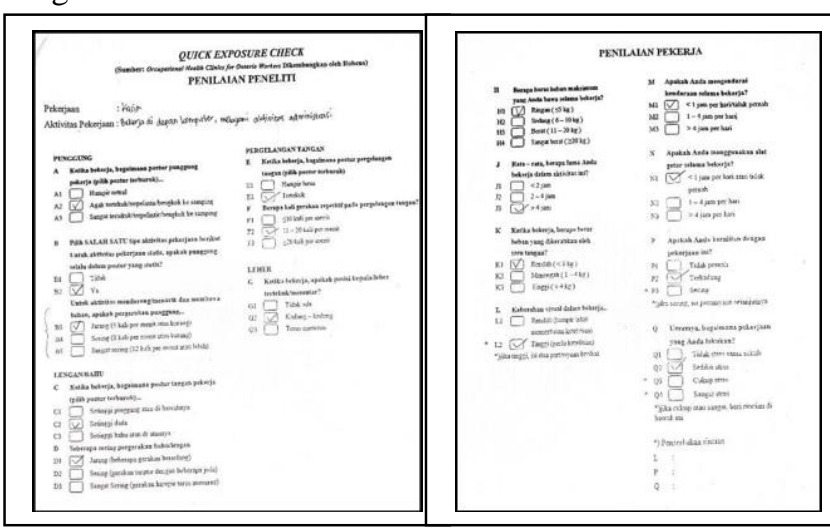

Figure 4. Assessment of Body Risk Levels.

\subsection{Data Processing}

From the known angle data obtained the results of the ErgoFellow analysis are shown in Figure 5. 


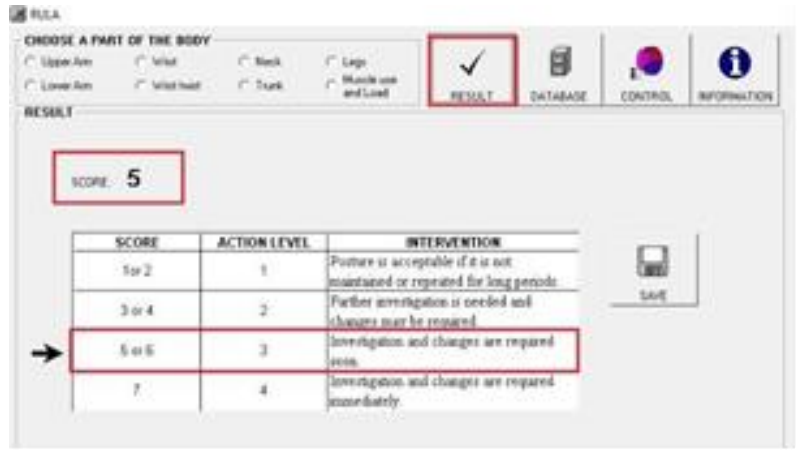

Figure 5. RULA Processing Results.

From the known question data, the ErgoFellow analysis results are shown in Figure 6.

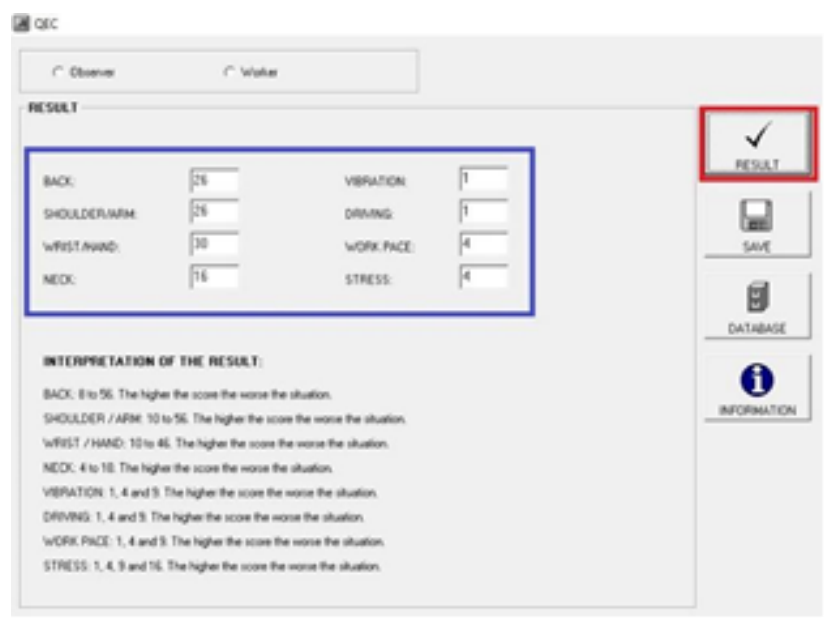

Figure 6. Exposure Score.

\subsection{Risk Analysis}

\subsubsection{Analysis of RULA}

From Figure 5 it is known that the operator's body posture when working, the final result is a score of 5 . From the RULA risk and action table, the risk level of the respondents working is included in the moderate risk classification or investigation and changes are required soon. The level of risk from this calculation can occur due to poor tool design and rest time scheduling. So that operators need to take immediate action and require immediate changes so that they do not have future risks.

\subsubsection{Analysis of $Q E C$}

From Figure 6, it is known that the respondent's body posture when working, the results of the exposure score are the back with a score of 26 , arms/shoulders with a score of 26, wrists with a score of 30 and the last is the neck with a score of 16 . From all scores obtained from several parts of the body, it can be seen that the total score is 98

Next, calculate the exposure level with the following formula (1):
$\mathrm{E}(\%)=\mathrm{X} / \mathrm{X} \max \times 100 \%$

Where:

$\mathrm{X}=$ Total score obtained

$\mathrm{Xmax}=162$ (static activity)

Based on the formula (1), the exposure level of the working posture when the operator is working, namely:

$$
\mathrm{E}(\%)=98 / 162 \times 100 \%=60.49 \%
$$

The exposure results obtained are classified as investigated further and change soon, which means the operator's activities or activities require certain research and require changes. This can happen due to many factors, for example, the working time is too long, the chair used by the operator does not meet the standards and other factors.

\section{CONCLUSION}

Body posture has an effect on the effectiveness of the cashier's work, this is shown from the analysis results that the score of the operator's risk level at work is 5 or a moderate level of risk. Based on the results of the QEC analysis that has been carried out, it can be seen that the Exposure Level perceived by the respondent is quite high so that the respondent's work posture requires further investigation and immediate changes. To obtain better work productivity, engineering control can be carried out, especially tool redesign or repair of work tools on chairs and tables so they more comfortable, making changes to the layout of the workplace, and automation. In addition, administrative control can be carried out, especially the scheduling of respondent's rest time and stretching every certain unit of time.

Based on this research, it can be developed further such as increasing the number of respondents and more variations in places. In addition, from the results of the analysis, an ergonomic work station design can be made according to the anthropometric measurements of the workers for better results.

\section{REFERENCES}

[1] Peraturan Menteri Kesehatan Republik Indonesia Nomor 35 Tahun 2014 tentang Standar Pelayanan Kefarmasian di Apotek.

[2] B. Yeats, "Factors that may influence the postural health of schoolchildren (K-12)," Work, vol. 9, pp. 45-55, 1997.

[3] A. N. Bintang and S. K. Dewi, "Analisa Postur Kerja Menggunakan Metode OWAS dan RULA," Jurnal Teknik Industri, vol. 18, pp. 43-54, 2017.

[4] N. Nurfajriah and R. Arifati, "Analisis Ergonomi Pada Proses Pembuatan Tahu Untuk Mengurangi Resiko Cidera Musculoskeletal Disorder (Msds)," 
Tekmapro: Journal Of Industrial Engineering And Management, vol. 13, pp. 19-30, 2018.

[5] A. N. Khofiyya, A. Suwondo, and S. Jayanti, "Hubungan Beban Kerja, Iklim Kerja, Dan Postur Kerja Terhadap Keluhan Musculoskeletal Pada Pekerja Baggage Handling Service Bandara (Studi Kasus Di Kokapura, Bandara Internasional Ahmad Yani Semarang)," Jurnal Kesehatan Masyarakat (Undip), vol. 7, pp. 619-625, 2019.

[6] V. H. V. Maligaya et al., "D7-2 Ergonomic Assessment of the Working Conditions of Checkout Counter Cashiers in a Grocery Store in the Philippines," The Japanese Journal of Ergonomics, vol. 53, pp. S612-S615, 2017.

[7] L. C. Roxô et al., "Work activity and musculoskeletal symptoms in female cashiers," Rev Bras Med Tra, vol. 19, pp. 324-331, 2021.

[8] Sutalaksana, dkk., Teknik Perancangan Sistem Kerja. Bandung: Penerbit ITB, 2006.

[9] P. B. Roxas and M. A. Ramirez, "Ergonomic Risk Assessment of the Production Process of Company X, Calamba City, Laguna, Philippines,” Asian
Journal of Research in Business and Management, vol. 3, pp. 13-25, 2021.

[10] F. Tayyari and J. L. Smith, Occupational ergonomics: Principles and applications. Chapman \& Hall, 1997.

[11] M. Middlesworth, "A Step-by-Step Guide to the RULA Assessment Tool,” Ergo plus, 2020.

[12] N. I. Rahman et al., "Anthropometric measurements among four Asian countries in designing sitting and standing workstations," Sādhanā, vol. 43, pp.1-9, 2018.

[13] L. McAtamney and E. N. Corlett, "RULA: Survey Method for The Investigation of Work-Related Upper Limb Disorder, Applied Ergonomi,” Journal of Human Ergonomics, vol. 24, pp. 91-99, 1993.

[14] B.P. Maharani, B. Aribowo, and N. Nurhasanah, "Usulan Perbaikan Postur Kerja Karyawan CV. Atham Toy's Mainan Kayu (ATMK) Dengan Metode Quick Exposure Check,” Jurnal Pasti, vol. 9, pp. 238-247, 2015.

[15] N. Staton et al., Handbook of Human Factors and Ergonomic Methods. USA: CRC Press, 2005. 